\title{
Emotion and Interest in Marriage and Domestic Power: Some Results of a Research in Portugal
}

\author{
Manuel Carlos Silva \\ Department of Sociology, Interdisciplinar Centre of Social Sciences (CICS.Nova_UMinho), CEAM, University of Brasília, Brasília, Brazil
}

Email address:

mcsilva2008@gmail.com

\section{To cite this article:}

Manuel Carlos Silva. Emotion and Interest in Marriage and Domestic Power: Some Results of a Research in Portugal. Humanities and Social Sciences. Vol. 7, No. 3, 2019, pp. 100-114. doi: 10.11648/j.hss.20190703.13

Received: January 10, 2019; Accepted: May 5, 2019; Published: June 29, 2019

\begin{abstract}
Having as a framework the reality of household and family relations in Portugal, this paper focus on the marriage as part and as strategy in the process of reproduction and eventual social mobility, which has been increasingly institutionalized over time and subject to the norms and prescriptions of moral, religious and/or state order. After a brief initial reflection on marriage and its components - emotion and interest -, the motivations and the resources, the importance attached, then domestic power will be subject of analysis based on the data collected. It will be revealed the marriage property regime, the values of the assets by the partners before marriage, the division on decision making, by sex, on certain matters, and money management in the household, the couple's shared moments, and their initiatives and forms of communication.
\end{abstract}

Keywords: Marriage, Emotion, Interest, Domestic Power, Gender Inequalities

\section{Introduction: Problem and Methodology}

Not only in the common sense perspective but also for some social scientists [1], is traditionally assumed that, while in the traditional, namely on peasant family, social relations and, in particular, marital choices were structured in function of calculated interest, the volume of economic goods (land, cattle), in modern societies it would prevail the emotion or love, being relegated to the background the interest dimension. Furthermore, within the marital unit catalysed by love, it wouldn't be a place to power struggles and conflicts in the management of several domestic issues. As we will show, both in the brief theoretical approach as in the empirical multiple expressions of conjugal units' lives, it is argued that problems persist and sometimes with intense conflicts leading to domestic violence.

Gender inequalities constitute a phenomenon that manifests itself in work and education access, in the extradomestic division of labour, in the employment structure and unequal wages namely in the private sector, the unequal opportunities in the access and progress in the professional careers, in the occupation of directive functions and political relevant positions, in leaderships rates, in institutional relations and also in several instances of power. However, also in the domestic sphere there is inequality on workload functions in the household and children care, husband and ascendants care that falls largely on women (for example, in Portugal, in a ratio of 9 hours per week for the woman versus the 3 hours for the man; [2-3]).

Based on the reality of family relationships within the framework of social classes, marriage emerges as a central strategy in the process of social reproduction [4-6] or social mobility [7-9] and/or reproduction with some social mobility [10-14]. In marriage, to a greater or lesser extent, there are two elements that have been present in various types of societies: passion and interest. Connected within the marriage - increasingly institutionalized over time and subject to the norms and prescriptions of the moral, religious and/or state order - lies another phenomenon even less openly recognized than the binomial emotion-interest: the domestic power.

After a brief initial theoretical reflection, this subject will be analyzed based on data collected in the framework of a coordinated research by the author on Gender inequalities in work and private life approved and funded by the Foundation for Science and Technology. In this research were crossed methods and techniques of quantitative order with others of qualitative order, emphasizing the comprehensive (verstehen) and interpretaive method in the wake of Weber [15] or in 
'embedded' (emic) perspective adopted in social sciences namely anthropology using narrratives and emotional testimonies of interviewed [6, 16-19]. The investigation was based on the collection, treatment and analysis on the results of a survey with 800 people, from rural and urban areas, and with diverse age groups, education levels and occupations, and 20 semi-structured interviews and field observation, in the Portuguese context.

This research on the combination of emotion, interest and power within the marriage assumes that, beyond the interests inherent to the macro-economic and institutional mechanisms, the domination, subjugation and sexual discrimination namely of the women is reproduced, reinforced or counteracted at various levels: socio-structural, organisational-institutional and interactive [20-31]. At meso and microsociological level. [3, 15, 18, 32-36], the power of each marital partner varies depending on the degree of provision on resources and rewards (marriage property regime, value of assets by partner before marriage and actually), the way and extent of participation in the production process, the degree of mobility and the presence/absence of hierarchy of sexual roles not only in the extradomestic division of labour but also on reproductive sphere of the family unit and the respective interactions and negotiations, in particular in the mentioned division and eventual overload of household tasks, in decision's making by sex on certain matters (vg. children activity, purchase of house or car, place of vacation), in the money management in the house, in the ways of how the couples share their several moments, in changing the ways of life of each one in the conjugality, namely at the birth and children upbringing, and in the forms of communication between the couple. Finally, some conclusions will be presented in the light of the mentioned problem.

\section{Marriage and Domestic Power: A Brief Theoretical Framework}

While developing a problematization of marriage and conjugality in Portugal, Analia Torres [37] reveals some of the core axes or dimensions of this institution and the pervasive reality of conservation and change: (i) as a link to the social life trajectory of each member of the couple; (ii) as a social fact that produces personal identities, stories and memories in a new context, which can be articulated with other social contexts such as the professional; (iii) as a strong affective component due to the feeling of love; (iv) as a source of reality in terms not only symbolic but also objective living conditions that imply sharing of resources within the framework of material conditions of existence; (v) as a social and historically situated phenomenon in close relation with the context.

Marriage and its patterns over time are often presented, namely by Shorter [1], in the framework of the structuralistfunctionalist current $[7,38]$, in a kind of dichotomy between interest-induced forms of union (most common in the past) and forms more centered on the emotions, affection or love (characteristic of modernity, especially since the industrial revolution), thus denoting a prejudiced view of the traditional rural classes and apologist of contemporary modern urban families. This thesis was, however, refuted by historians [39], anthropologists and sociologists [10, 13, 40-44], who have shown the relationhip between emotion and economy and that, in many places and times, interest and emotion goes hand in hand, even when the subjects themselves are not aware of it.

The debate on domestic power has been largely unexplained, as this would be considered inappropriate in an area reserved for emotion, affection, or love. However, it has been more indirect than directly addressed by some authors in the Portuguese context, namely in the Luso-Galician rural space and, in particular, in the Minho's region. Some authors such as Geraldes [45] and Iturra [46]) have emphasized male dominance or even patriarchal authority in peasant houses in Minho and Galicia when analising the androcentric tonic in the legal prescriptions and especially in social practices, namely the submissive, respectful and sometimes deferential behavior of the woman towards the husband (treating him, for example, by 'senhor'- 'sir'). On the other hand, authors such as Descamps [47] and Willems [48], based on ethnographic observations and, more recently, E. Santo [49], appealing to psychoanalytic approach in the variant of Jung's "collective unconscious", recognize patriarchal power, but they underline or even sublimate the telluric matricentrality of social relations in Minho. On the other hand, J. P. Cabral [50], based on arguments of a symbolic-valuative and linguistic-interactional nature (for example, designation of 'patroa'- mistress- by the husband), maintains on the conjugal power a "problematic" ambiguity. Finally, Brettel [51], in the context of the analysis of the dynamics of demographic and migratory movements in a small village, emphasizes, at the same time, the patricentrality and the matricentrality of the domestic groups.

If practices such as place of residence, the transmission of name and property, as well as conjugal strategies and interactions should be taken into account, the more it becomes important, to, while articulating them, focus on the analysis of the ways in which the composition of domestic groups and, above all, the redistribution of domestic power and eventual conflicts resulting from there are affected and conditioned by the degree and type of material and symbolic resources that each groom or bride brings with him/her or acquires pending the home enterprise: patrimonial assets, aesthetic and erotic attributes, physical experience and strength, skills, knowledge and qualifications, honor, prestige or local power.

Rodrigo Rosa [52], although starting from the moment of the creation of the couple, in which the choice of the spouse, especially among members of qualified couples, would tend to be on a homogeneous basis or socio-professional proximity, however problematizes, in agreement with Singly [53], the static concept of homogamy and especially summons the dynamic concept of conjugal trajectory based 
on the strategies of articulation between professional work and family life. In other words, the different modes of articulation between extradomestic work and family life, particularly by women and subsequent negotiation processes on the sexual division of domestic work and childcare, would in a minority of cases reflect in the consolidation of initial homogamy, but, in most situations, in the crystallization and amplification of social differentiation in favor of man. Hence, (i) a familial strategy on the part of the woman can give rise to a priority hypergamic trajectory (in which the woman renounces a professional career for the benefit of the husband); (ii) a maximalistic strategy of women, giving rise to a progressive hypergamic trajectory (in which the woman bets in a balanced way in the family and in the profession); (iii) a maximalistic granting strategy insofar as women, without renouncing career progression, make concessions to prioritize the career of the husband/partner within the framework of the maximalist strategy; (iv) a 'careerist' strategy in which women, while responding to family responsibilities, favor the aspirations of their professional career at the same level as their husbands, leading to the consolidation of a homogenous conjugal trajectory or, with a strategy less ambitious of her husband, forming a hypogamic strategy. Without denying the relevance of the conjugal strategies and trajectories and typologies presented by Rosa [52], social and gender inequality, as well as power asymmetries within couples, can not be reduced to strategic dimensions, but to multidimensional and pluri-level articulation in the combination of several structural and strategic factors: objective living condtions (eg. gender, class, ethnicity, age, nationality), habits and lifestyles, resources brought before marriage and/or acquired pending this, as well as normative, axiological and ideological constraints, which are not gender neutral.

In this context, it is important to distinguish the extent to which the ideology of sexual subordination goes hand in hand, as Dubisch [54] points out, with effective control over resources and decision-making ability, which includes, in addition to dominance over force work and others - when present or called - the planning and execution of domestic activities. The subordination also has repercussions on such matters as the procreation and upbringing of children, their marital and professional choices, or the return of goods or properties. On the other hand, notwithstanding the relevance of social representations and practices, especially around the sexual division of domestic activities [55], it is important not to obscure that in the domestic groups and their dynamics articulate and costructure national and international impacts, namely economic vectors of the global society and state determinations in the symbolic and political-juridical sphere [56-61]([56-61]). Finally, it should be emphasized that the cycles of formation, (re) composition, development and fission of houses, as places and nuclei of social reproduction, as well as the interweaving of interests and emotions with their respective strategic interactions within families form the dynamic and contradictory matrix of conservation, differentiation and transformation of social groups, as well as their practices and values of cooperation and conflict within the domestic units ${ }^{1}$ However, let us turn to the data obtained by survey and interviews, in order to test the relevance of this approach in the analysis of data about marriage and its gender relations.

\section{Marriage: Motivations and Resources}

A subject that has been analyzed and raises an increasing interest concerns the entry into conjugality, whose modalities, from the data obtained in the survey and without differentiating by sex, can be summarized in the following order of priority and importance: $39,4 \%$ for religious marriage followed by civil marriage, $28.8 \%$ for civil marriage followed by religious marriage, $14 \%$ exclusively for civil marriage, $9.8 \%$ for cohabitation and $5.9 \%$ for cohabitation followed by marriage, marriage civil $(1.6 \%)$ or religious/civil marriage $(0.5 \%)$. The combination of religious marriages followed or preceded by civil marriage predominates, making up a total of $67 \%$, an approximate figure for other surveys conducted in 1990 and 2000 and studies analyzed by Torres [37] (2002: 57ff). Despite a considerable decrease of $20 \%$ in religious marriages, especially the Catholics ones between 1960 and 2000, there still are a high percentage of religious marriages in Portugal. However, as Torres [37] rightly points out, there is a lack of coincidence between the option of celebrating Catholic marriage and conviction and, above all, religious practice (for example, in 1990 , from the $70 \%$ of Catholic marriages, only $33 \%$ were actual believers). That is to say, the celebration is not an indicator of belief and, much less, of religious practices, since religious marriages that take place by social control, by pressures of the parents of the groom and especially of the bride, by ritualism or pragmatism of the groom or/and bride, especially of grooms, namely indifferent, agnostic or atheists. In any case, this survey, compared with others in previous decades, confirms a certain downward trend in religious marriages and a rise in exclusively civil marriages and de facto unions.

A first and crucial decision concerns family planning for children. According to the survey respondents, the majority of the children were planned, mainly the first ones $(69.3 \%)$, the second ones $(70.6 \%)$ and the third ones $(56.4 \%)$; to a lesser extent, the forths (38.9\%) and, in a less expressive way, the fifths $(15.4 \%)$ and the sixths $(14.3 \%)$ children. As a rule, these decisions are consensual, although there are cases where women surprise the groom or husband: "There was no planning, because my ex-wife decided from one moment to the next to get pregnant without warning me (E12, male, 42 years, worker, divorced).

On the motivations and objectives, between men and women, regarding marriage, Figure 2 shows some differentiations by sex. Although there are no major

1 As evidenced, among others, by [66], [67], [22], [68], [69], [40], [41], [70], [71], [72], [73], [74] and, in Portugal, [58], [75], [76] [13], [77] [78], [79], [80], [37] [52]. 
discrepancies in the initial motivations of men and women for getting married, it is noted by men that there is a greater emphasis, in an institutional register, on the motivation to "form a family and have children" (30.8\% vs 22.7\%), contrasting a little with women's motivation to "have a home and a house to their liking" (27.1\% vs $24.9 \%)$. In second place and in approximate percentages $(22.7 \%$ in women and $22.4 \%$ in men) the purpose to "live in love" follows, converging with the conclusion of Torres (2002: 101) [37], which found that the love feeling is central, although not enough, for the success of the marriage. Third, there are answers that point to the perception of marriage as a privileged space for "having a company, dialogue and understanding" and, to a lesser extent, "having independence from the origin family", one and another more adopted by women than by men (respectively $13.9 \%$ and $2.8 \%$ vs $10.5 \%$ and $0.8 \%$ ), to which it will be added, more by men than by women, "share similar interests and ideas" (4.2\% vs. 1.6\%).

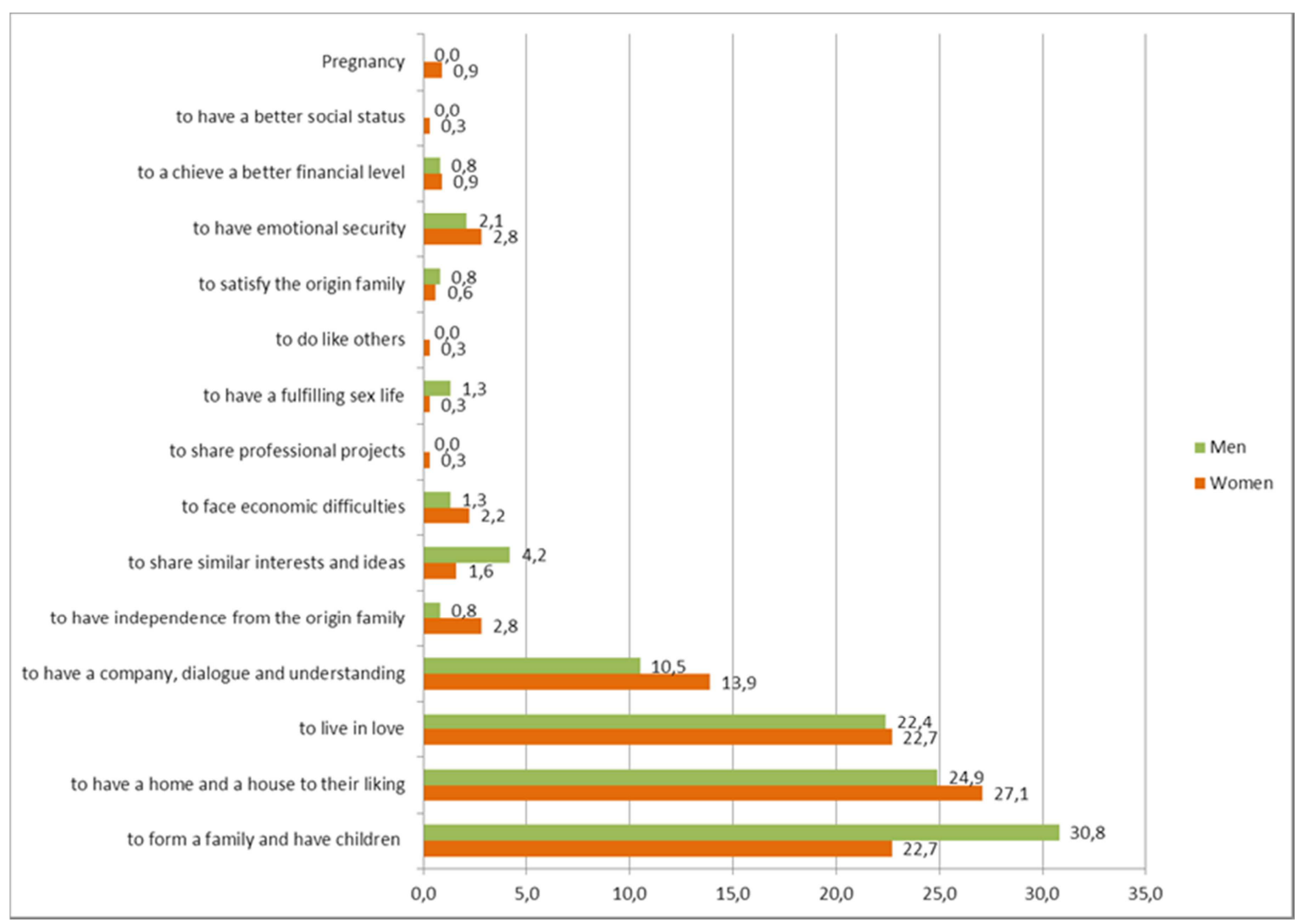

Source: IDG; N=559 (239 men; 320 women).

Figure 1. First motivation for marriage, by sex (\%).

Thus, balancing the responses expressed in Figure 1, we can verify common goals (family formation and having children) with other material ones (having a home) and psycho-affective gratification (company/dialogue, understanding). In order to illustrate these motives, let us look at the synthetic expressions of a woman and a man interviewed: "We marry to be together, to have children, and to have a home, a home and start our lives with us two, closer" (E21, woman, auxiliary in educational); or "Creating a family, having children, having our little house that was not easy at the time. I was fortunate enough to get through my parents [help] to restore an old house" (E16, man, civil servant). In order to more accurately analyze the motivations for marriage by profession and sex, four respondents with the highest response frequency are shown in Table 1.

Table 1. First Motivation for Marriage by Profession and Sex.

\begin{tabular}{|c|c|c|c|c|c|c|c|c|c|}
\hline \multirow[t]{2}{*}{ Profession } & \multirow[t]{2}{*}{$\mathrm{N} / \%$} & \multicolumn{2}{|c|}{$\begin{array}{l}\text { Having a home } \\
\text { and a house to } \\
\text { their liking }\end{array}$} & \multicolumn{2}{|c|}{$\begin{array}{l}\text { Having company, } \\
\text { dialogue and } \\
\text { understanding }\end{array}$} & \multicolumn{2}{|c|}{ Living in love } & \multicolumn{2}{|c|}{$\begin{array}{l}\text { Forming a family } \\
\text { and having } \\
\text { children }\end{array}$} \\
\hline & & M & W & M & $\mathbf{W}$ & M & $\mathbf{W}$ & M & $\mathbf{W}$ \\
\hline \multirow{2}{*}{$\begin{array}{l}\text { High managers, specialists of intellectual and } \\
\text { scientific professions }\end{array}$} & $\mathrm{N}$ & 0 & 3 & 0 & 2 & 2 & 5 & 3 & 2 \\
\hline & $\%$ & 0,0 & 25,0 & 0,0 & 16,7 & 28,6 & 41,7 & 42,9 & 16,7 \\
\hline \multirow{2}{*}{ Litle entrepreneurs } & $\mathrm{N}$ & 5 & 3 & 1 & 1 & 1 & 6 & 5 & 1 \\
\hline & $\%$ & 31,3 & 25,0 & 6,3 & 8,3 & 6,3 & 50,0 & 31,3 & 8,3 \\
\hline \multirow{2}{*}{ Technicians and middle rang professionals } & $\mathrm{N}$ & 1 & 5 & 1 & 0 & 1 & 5 & 6 & 3 \\
\hline & $\%$ & 9,1 & 35,7 & 9,1 & 0,0 & 9,1 & 35,7 & 54,5 & 21,4 \\
\hline
\end{tabular}




\begin{tabular}{|c|c|c|c|c|c|c|c|c|c|}
\hline \multirow[t]{2}{*}{ Profession } & \multirow[t]{2}{*}{$\mathrm{N} / \%$} & \multicolumn{2}{|c|}{$\begin{array}{l}\text { Having a home } \\
\text { and a house to } \\
\text { their liking }\end{array}$} & \multicolumn{2}{|c|}{$\begin{array}{l}\text { Having company, } \\
\text { dialogue and } \\
\text { understanding }\end{array}$} & \multicolumn{2}{|c|}{ Living in love } & \multicolumn{2}{|c|}{$\begin{array}{l}\text { Forming a family } \\
\text { and having } \\
\text { children }\end{array}$} \\
\hline & & $\mathbf{M}$ & W & $\mathbf{M}$ & $\mathbf{W}$ & $\mathbf{M}$ & $\mathbf{W}$ & M & $\mathbf{W}$ \\
\hline \multirow{2}{*}{ Administrative personnel and similars } & $\mathrm{N}$ & 0 & 9 & 0 & 3 & 3 & 8 & 4 & 1 \\
\hline & $\%$ & 0,0 & 37,5 & 0,0 & 12,5 & 37,5 & 33,3 & 50,0 & 4,2 \\
\hline \multirow{2}{*}{ Service personnel and sellers } & $\mathrm{N}$ & 0 & 5 & 0 & 17 & 4 & 12 & 0 & 10 \\
\hline & $\%$ & 0,0 & 10,2 & 0,0 & 34,7 & 100,0 & 24,5 & 0,0 & 20,4 \\
\hline \multirow{2}{*}{ Peasants and qualified workers of agriculture } & $\mathrm{N}$ & 0 & 4 & 0 & 1 & 2 & 2 & 4 & 4 \\
\hline & $\%$ & 0,0 & 36,4 & 0,0 & 9,1 & 33,3 & 18,2 & 66,7 & 36,4 \\
\hline \multirow{2}{*}{ Workers, artisans and similars workers } & $\mathrm{N}$ & 5 & 5 & 8 & 1 & 14 & 4 & 14 & 5 \\
\hline & $\%$ & 11,1 & 27,8 & 17,8 & 5,6 & 31,1 & 22,2 & 31,1 & 27,8 \\
\hline \multirow{2}{*}{ Operators of instalations and machines } & $\mathrm{N}$ & 6 & 0 & 3 & 1 & 4 & 0 & 5 & 0 \\
\hline & $\%$ & 27,3 & 0,0 & 13,6 & 100,0 & 18,2 & 0,0 & 22,7 & 0,0 \\
\hline \multirow{2}{*}{ Not qualified workers } & $\mathrm{N}$ & 5 & 9 & 2 & 5 & 3 & 8 & 2 & 11 \\
\hline & $\%$ & 38,5 & 24,3 & 15,4 & 13,5 & 23,1 & 21,6 & 15,4 & 29,7 \\
\hline
\end{tabular}

Source: IDG, 2011; N=275; M=Men: W=Women.

In all professional groups, the high motivation to "form a family and have children" (between $66.7 \%$ and $42.9 \%$ ) is highlighted, although in a differentiated way: more accentuated among peasants/farmers, administrative and service personnel and senior staff and specialists in the intellectual and scientific professions (and more between men than women), and less between unskilled workers and workers. Although with smaller and more sparse percentages, "living in love" is mainly referred to by professions considered higher or with more resources to the detriment of professions with more modest incomes: workers and unskilled workers. "Having company, dialogue and understanding" arises but in reduced percentage values in almost all professional groups; finally, "having a home and a house to their liking" is roughly referred to in percentage terms by almost all professional groups (between $9 \%$ and $40 \%$ ), although more markedly among women.

These answers will be in line with the alleged however refutable thesis that in modernity people orient themselves in marriage by love and not, as in the past, by interest (c [1] f.), as well as with the subsequent and prejudiced narrative about the said high-ranking classes oriented more by love than by interest in contraposition to marriages of other classes such as peasants being most interest-oriented (land, livestock). In fact, several studies, despite eventual sworn statements of 'pure love' by certain protagonists, indicate and prove that the elements of the passion-interest binomial are, to a greater or lesser extent, present in several social classes, both in the past and in the present [10, 13, 40-41]. Also Kaufman [62], when analyzing the donation in marital exchanges, takes away from an angelic vision of pure donation, sustaining that it is permeating by negotiation or even mined by calculations, often short termed, going in the direction of interested reciprocity concept (do ut des) sustained by Weber [15].

The average of importance, for both men and women, is high, close to the maximum score of 3, as can be seen in Figure 2:

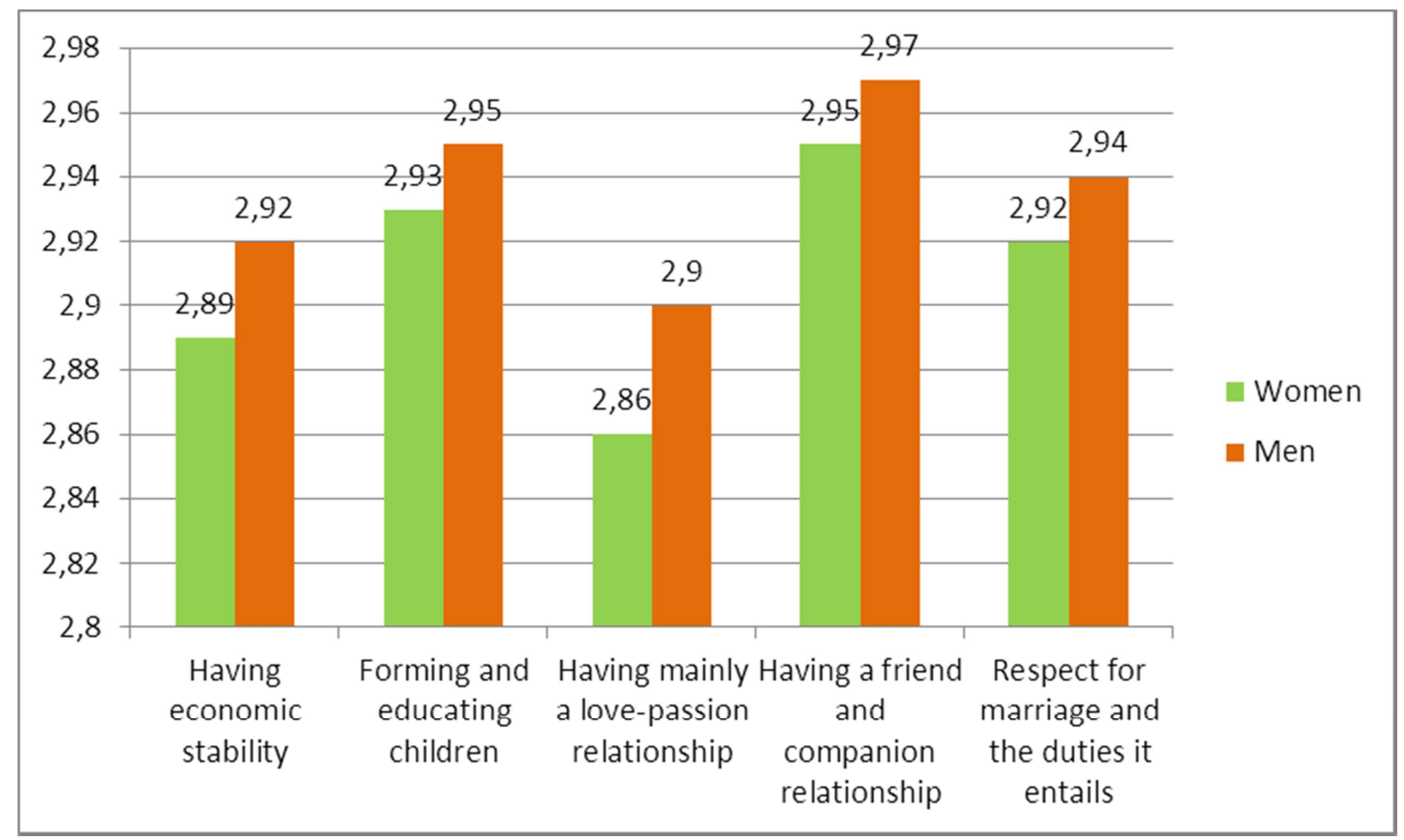

Source: IDG; N=559 (239 men; 320 women).

Figure 2. Average of importance atributed to dimensions in marriage, by sex. 
If marriage has been in the past, especially in discursive terms, a relationship with strong meaning, today, both for men and for women, seems to be increasingly relativized with the functional equivalent of the in facto union or is often overlapped, following the terminology of Giddens (1992) [63] and Beck and Beck-Gernsheim (1995) [64], of diverse conceptions and troubled trajectories. For example, the following interviewee reports:

"I dated and got married; it was a little troubled because I needed to leave the house and from there I got married. It was a very troubled phase and it was a romantic relationship not accepted by my stepmother, because she wanted me to have a girlfriend and married one of the other women, women of possessions, and I did not want that. I married to leave the house after the end of the military service and because I liked my ex-wife". (E12, male, 42, worker, divorced)

And another interviewee says:

"I dated before I got married, I did not get married. I lived in facto union with the father of my daughter, then I got separated and then I had another facto union (...). I have a relationship for 10 years with the same person. I appreciate this time and I do not like changes. I always spend a lot of time with the same person and I think it was a good time." (E10, woman, 35, employed, separated).

There are certainly many testimonies that affirm relationships of love-passion, of love-affection, above all at the time of dating and beginning of marriage ("It was very cool, very beautiful", E17, woman, secretary), but there are others that are crossed by feelings of dissatisfaction and hate that often lead to separation and divorce. There are, however, cases where the love-hate relationship persists during marriage or even after the separation and death of the (ex) spouse:

"My parents's relationship was good up to a certain point, until the day my father decided to get a girlfriend and my mother asked for a divorce. He has always been very fond of her; he did not stay with this girlfriend and every weekend he would take the grosseries there to my house and made sure to always send the things that my mother liked.... He died and my brothers and I only buried him, and no one ever returned to the cemetery; except my mother, my mother goes to his grave, my mother takes care of his grave (...). It was a relationship of love and hate; but she never remarried, she only had this marriage, she never had a boyfriend, she is a widow "(E11, woman, 37 years, employed, separated).

In addition to cases of infidelity, it was mainly the situations of psychic violence and above all physical abuse that caused feelings of rejection and even hate with subsequent separation / divorce:

"It's inexpressible. I've been raped many times. It is horrible to end up making love with a person and to be accused of having relations with the neighbor... I had to flee many times when he came behind us with a knife and I have to flee to the street, hide and spend the night in the snow... or else be kicked in the middle of the street, all the way home. I had to be taken to the hospital by the neighbors because he was so restless and serene looking at me and without being able to move... But the factor that triggered our separation was the violence he began to transmit to my daughter. When my daughter started to get in between me and him and he started to not be able to hit me, then started to hit my daughter and I started to see my daughter like an animal lying on the ground, I said: I do not want for my daughter what I went through... This has no solution for me or my daughter... It was really gaining hate, not being able to take it anymore... It was my 80 -year-old godmother who gave me the chance to leave home" (E23, woman, worker, artisan and over-the-counter maid).

Continuing to deal with other data obtained on marriage, another question concerns the adopted or applied marriage property regime, which, as a whole, is distributed as follows: $56.5 \%$ by general communion of goods, $39.6 \%$ by acquired common goods and $3.9 \%$ by total separation of assets. Although since 1966 the rule has been that of acquired common goods, the still high percentage of the generall communion regime is related to the fact that older people have married under this regime. However, after the revision of the Civil Code of 1966, the regime of general communion of goods, such as that of total separation of goods, became subject to a prenuptial agreement.

Another fundamental question is to know to what extent men and women share not only tasks but also the power of disposition or control over resources and how the decisionmaking power is distributed in the most varied subjets. In this context, considering the advanced hypothesis that the power of disposition of women (as indeed that of men) differs according to the possession of certain resources before and during marriage, the analysis will focus on the amount of property owned before the marriage in custody by men and women. In the vast majority of cases, respondents reported that they did not own property before marriage: in fact, only 126 people (16\% of respondents and $23 \%$ of those involved in conjugal relations) reported having property before marriage, and only 98 indicated that the spouse did own it (12\% of respondents and $18 \%$ of those involved in conjugal relations). This means that in more than $75 \%$ of conjugal relationships there is no property/heritage/goods before/previous to marriage, which is consistent with the sociodemographic characteristics of the sample. Of the remaining 16\% who had goods before marriage, we can obtain in Figure 3 an estimate of their volume by sex: 


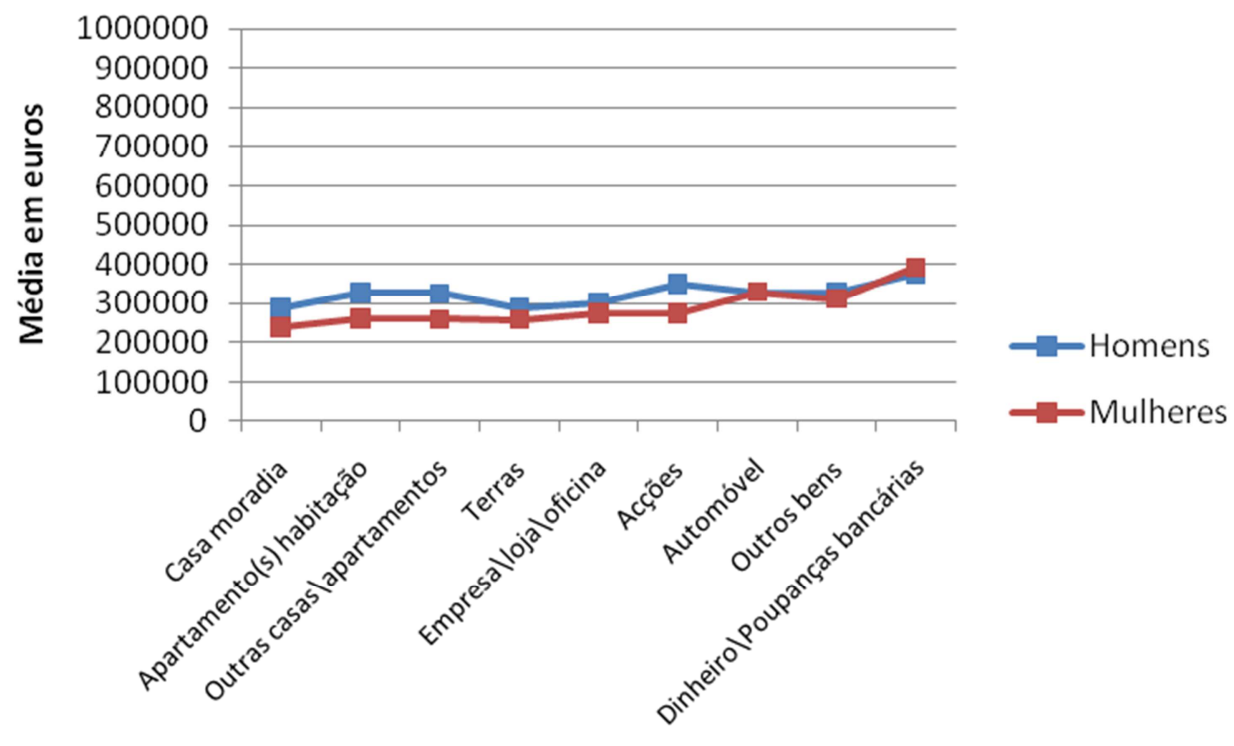

Fonte IDG, 2011; N=98; blue=Men; red=women

Figure 3. Value of partner's assets before marriage, by sex (\%).

Figure translation: Homens= Men; Mulheres= Women; Casa moradia=House; Apartamento(s)habitação=Apartment(s); Outras casas/apartamentos=Other houses/apartments; Terras=Land; Empresa/loja/oficina $=$ enterprise/shop/factory; Ações=shares; Automóvel=Car; Outros bens=other goods; Dinheiro/poupanças bancárias= Money/bank savings.

Although not very marked, there is a difference in the ownership of resources, especially patrimonial, real estate and land, having men, on the whole, an advantage over women. Also, the salary level, if in most cases does not matter, may in others influence the degree of power of each member of the couple in the house:

"I think sometimes, for example, the financial question can influence a lot, one earns more than the other; I think the person who earns more, if that difference is substantial, may feel that he should have the power to make more decisions about how that money is going to be spent. Then, it has to do with the personality of the couple's members, and I think it also evolves over time, things are not always the same. "(E11, woman, 37, divorced, bankworker).
This same idea is shared by one of the interviewees:

"Power in the family was never divided fairly. There is almost always a leader. This leader in general is the man, which is not to say that in some cases (not rare) is not the reverse. And because this process of power is related to many factors such as: the character of each one, the maturity of one and the other (usually the one with the highest salary tends to lead), there is also the cultural factor that for centuries determined that the woman was the weak sex and, as such, should be obedient to her husband "(E28, man, teacher).

Focusing on the analysis of the quantity of goods in the present time, already in the context of marriage, it is verified, according to Figure 4, a relative proximity in the volume of resources between men and women.

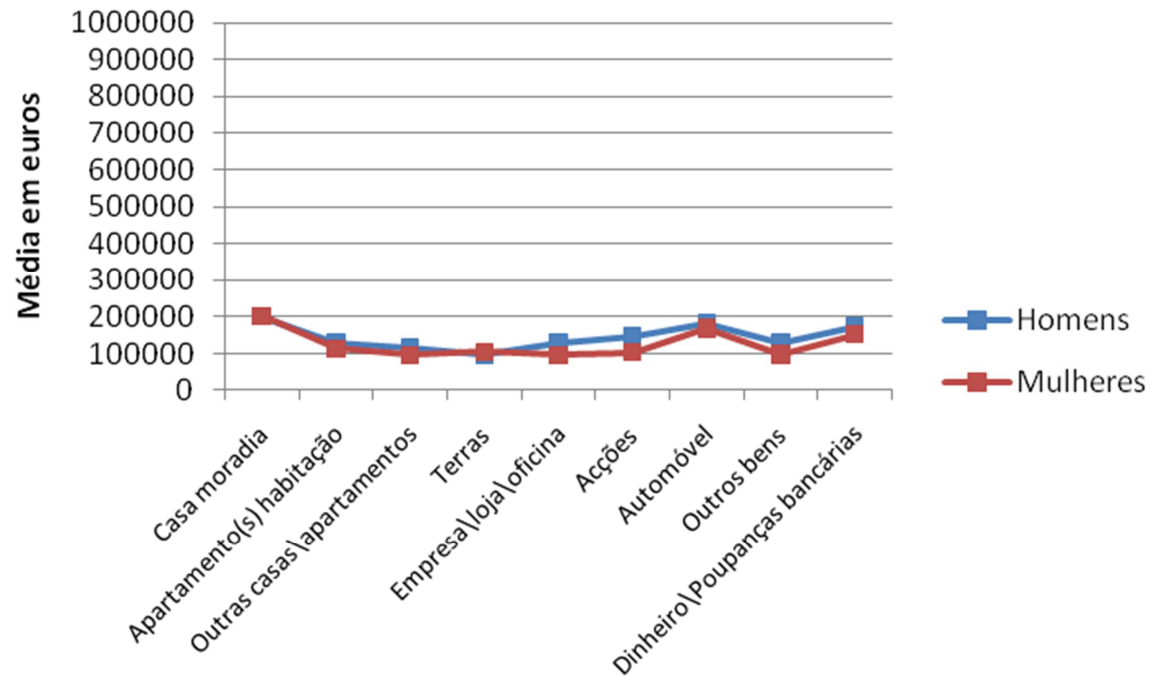

Fonte IDG, 2011; N=272.

Figure 4. Current partners's assets, by respondent's gender. 
Figure translation: Homens $=$ Men; Mulheres $=$ Women; Casa moradia=House; $\quad$ Apartamento(s)habitação=Apartment(s); Outras casas/apartamentos $=$ Other houses/apartments; Terras=Land; Empresa/loja/oficina $=$ enterprise/shop/factory; Ações=shares; Automóvel=Car; Outros bens $=$ other goods; Dinheiro/poupanças bancárias $=$ Money/bank savings.

With regard to the assets of the spouse currently owned by the respondent's sex, there is also a proximity in the set of assets, and a relative advantage of the men with regard to the company or workshop, the number of shares, the automobile and others goods, money or bank savings. This proximity not only to the possession of own goods brought and/or maintained during the marriage, but also to income has led certain authors to proclaim themselves to be facing a loss of traditional power of man or even a "crisis of masculinity". The man, feeling threatened in his position, no longer fulfills exclusively or predominantly the function of provider of the family, which is evidently an ideological drift of the traditional standard.

\section{Domestic Decision-Making Power and Communicative Dynamics of the Couple}

The vast majority of family decisions - whether they are "commitments for activities to be carried out by children", "choice of vacation location", "car purchase" or "home purchase" - tends to be taken jointly by both members of the couple, the percentages in all cases being higher than $59.8 \%$. Notwithstanding the percentage of respondents who have not taken decisions at these levels, the choice of "holiday location" and "home purchase" - which may certainly be related to purchasing power - is to emphasize, in all cases, circumscribing the analysis in mutually exclusive terms, a tendency, however tenuous, for the self-attribution of roles and decisions. Figure 5 shows the self-perceptions in terms of the respondent's gender decision:

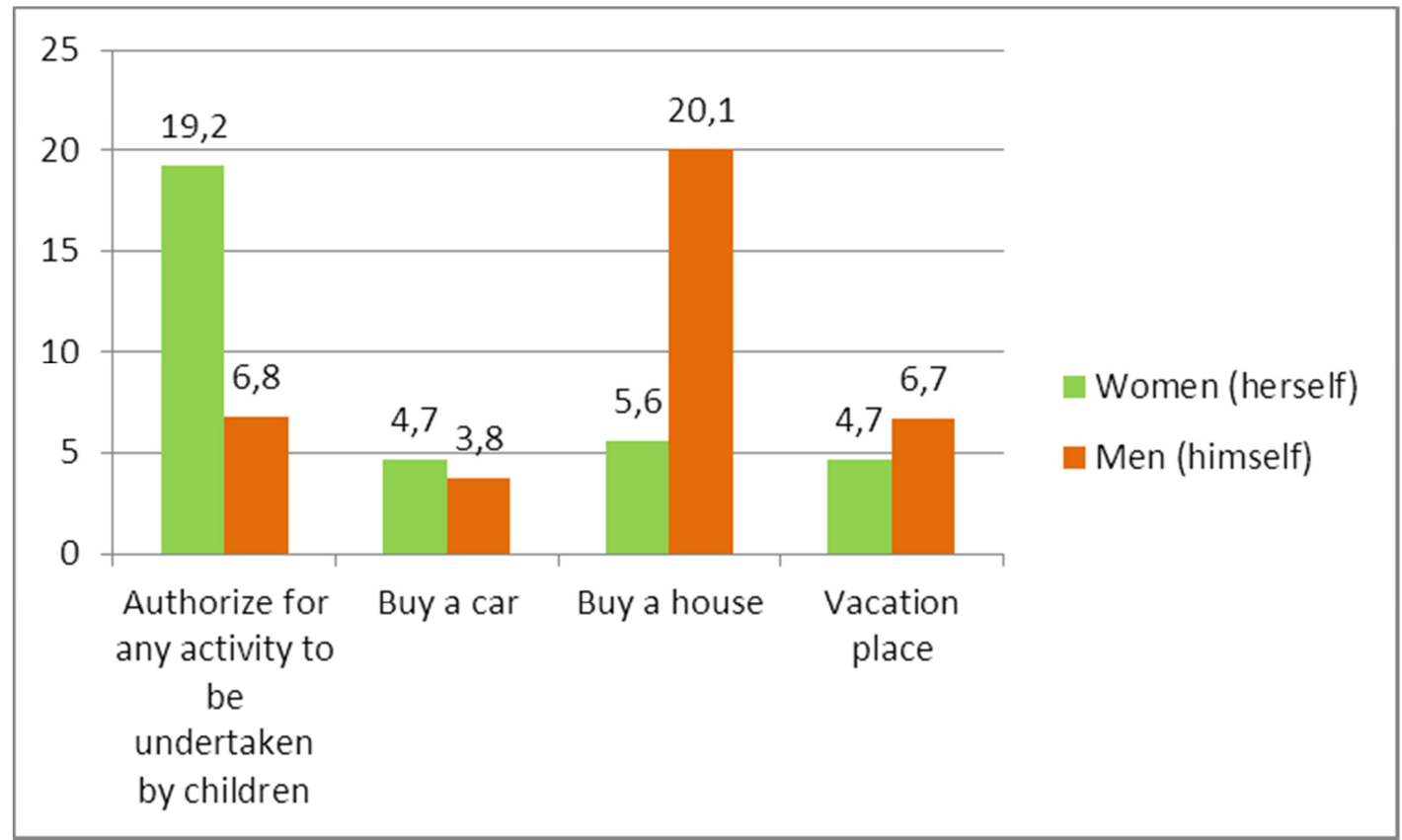

Source: IDG, 2011; N=559 (239 men; 320 women).

Figure 5. Decision-making, by sex, on certain subjects (\%).

Figure 5 illustrates that sex (or gender roles) tends to count relatively on who makes the decision on some subjects. There are significantly more women deciding "authorize for any activity to be undertaken by children" (19.2\% vs 6.8\%); more men to decide to "buy a house" (20,1\% vs 5,6\%); as well as choose "vacation place" and to "buy a car" assume very close percentages $(4.7 \%$ in both cases for women and $6.7 \%$ and $3.8 \%$ respectively for men). Some expressions conveyed in the interviews reinforce the idea that, except for exceptional cases, it is the man who has more decision power in matters considered of greater economic value, often because the husband has a higher income, as one interviewee says:
"In terms of business, he was almost always the one who had the most power over me, because as he earned more and had more competence for the business, it was he who decided the business he was doing, buying land and other things" (E17, woman, conservative restorer of sacred art).

There are, however, other registers of opposite sign:

"I think the one who has the most power is the woman, although it often makes it seem like it's the man, but deep down, they [women] are the ones who decide... He has the last word, but in the meantime she has already prepared the way. In general, the woman in this aspect is manipulative, so to speak "(E28, woman, superior technique).

"The woman commands more than the man, although it 
may not seem that way. The woman is the keystone with the children. The woman is the balance. In my case there was something like blackmail... I was saturated. Let's say it must have been one of the causes of the divorce "(E18, man, employment technician).

Others, however, achieve a certain balance:

"In our relationship there was always that agreement to avoid command, because I do not even like that word. There are couples in which the man is the most bossy. Now with me there was always harmony. One must know how to ask with respect "(E16, man, civil servant).
Given the totality of the itens, there is a tendency for decisions that imply more directly monetary costs to be perceived as more assumed by men and the rest by women. As we will see below, this does not imply that the organization of the money or its availability is not perceived as assumed by both members of the couple.

An important form of management and household power, now more or less shared or more or less individualized, is the management and organization of money in the family context, as can be seen in Figure 6.

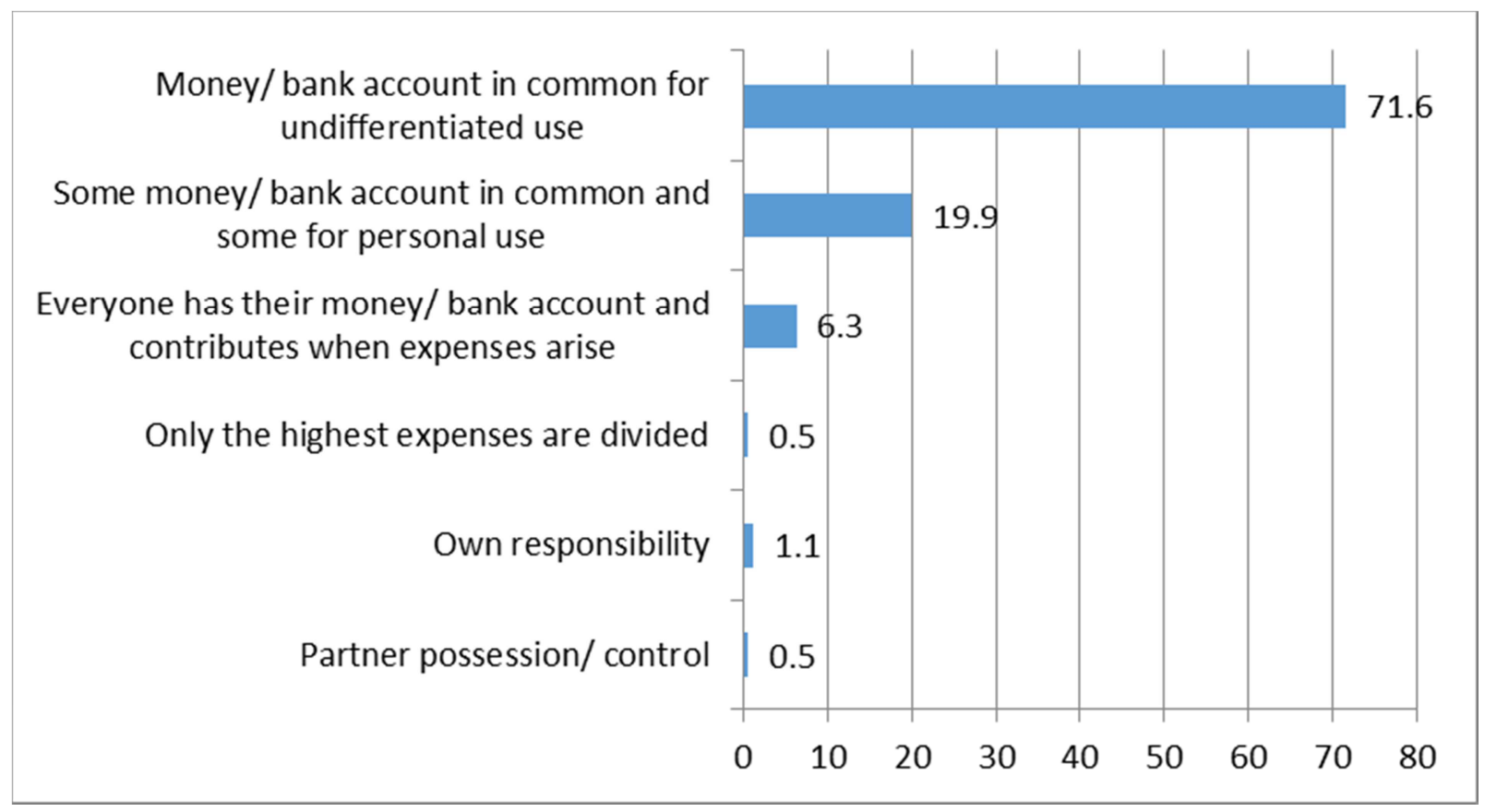

Source: IDG, 2011; N=559.

Figure 6. Organization of money at home (\%).

As we have seen, in $71.6 \%$ of the cases, respondents say they have "money/ bank account in common for undifferentiated use"; followed by $19.9 \%$ of cases claiming to have "some money/ bank account in common and some for personal use." More individualized forms of money management in the couple are claimed to be residual $(8.4 \%$ in total), which indicates that, in the Portuguese case, we are far from the process of individualization of the intimacy relations referred to by Giddens [63], Beck [64] and Bauman [65] in certain contemporary societies.

Another relevant aspect refers to the more or less fusional tendencies or individualization within the couple. Based on the total sample of married/divorced individuals, we found that $75 \%$ of respondents reported sharing or having shared with their (former) spouse "all moments, tastes and friends in an intense way"; in $19.1 \%$ there are those who claim to share and/or shared "a common life with her/him, but to keep certain moments, tastes and friends to her/himself". More individualized experiences, expressed in the option "each one has or had their own moments, tastes and friends", assume poor expression (5.9\%). A gendered and discriminant analysis does not show relevant differences at this level between men and women, as shown in Figure 10.

As shown in Figure 7, the types of relationships with the spouse by gender do not differ that much. However, a slightly higher percentage is observed for women in extremes - that is, in the fusional mode of sharing moments, interests and friends $(75.3 \%$ vs $74.5 \%)$ and in the more individualistic modality of spaces, interests and friends $(7.2 \%$ women $v s$ $4.2 \%$ men), with men predominating in a mixed form of sharing and self-reserve $(21.3 \%$ vs $17.5 \%)$. In any case, to a greater or lesser degree, it was also possible to observe the presence in many couples and de facto unions of the imbrication of two elements - interest and passion and/or affection, as one interviewee observes:

"In our married life there is interest and affection, relations of interest because we have to build something, do not we? But if we have a woman at our side and if we want a woman at our side, it is not only to have goods, it will also be to have a little love and affection and we must give affection and receive affection, no? "(E2, man, 43 years old, divorced, construction worker).

Based on various forms of conjugality, namely the fusional or associative (Torres 2002: 39ff) [37], and 
having the interviewees responded about the most important aspects of a couple's life, the answers, expressing common aspects, denote some differentiation in the now more fusional or more associative sense. For example, in fusion terms: "It is living exclusively for each other. It's not 'I go with my friends, you go with yours'. It is to run to the same side "(E24, man, accounting technician); or: "Sharing tasks, sharing responsibilities, sharing affections, in all respects" (E19, woman, superior technique). In intermediate terms: "I think a good deal of confidence, friendship, affection and affection are fundamental" (E15, woman, tax technique); or: "Above all, honesty, a good dialogue and affection. These are the three points I emphasize most "(E16, man, civil servant). Already in an associative orientation: "Fellowship, complicity, openness also, freedom for both parties" (E18, man, employment technician, lawyer); or "It is communicating with one another. And participating in things and having first of all understanding between the two. If they are not trying to communicate with the same goals or try to agree, at least try to balance and friendship "(E17, woman, conservative of sacred art).

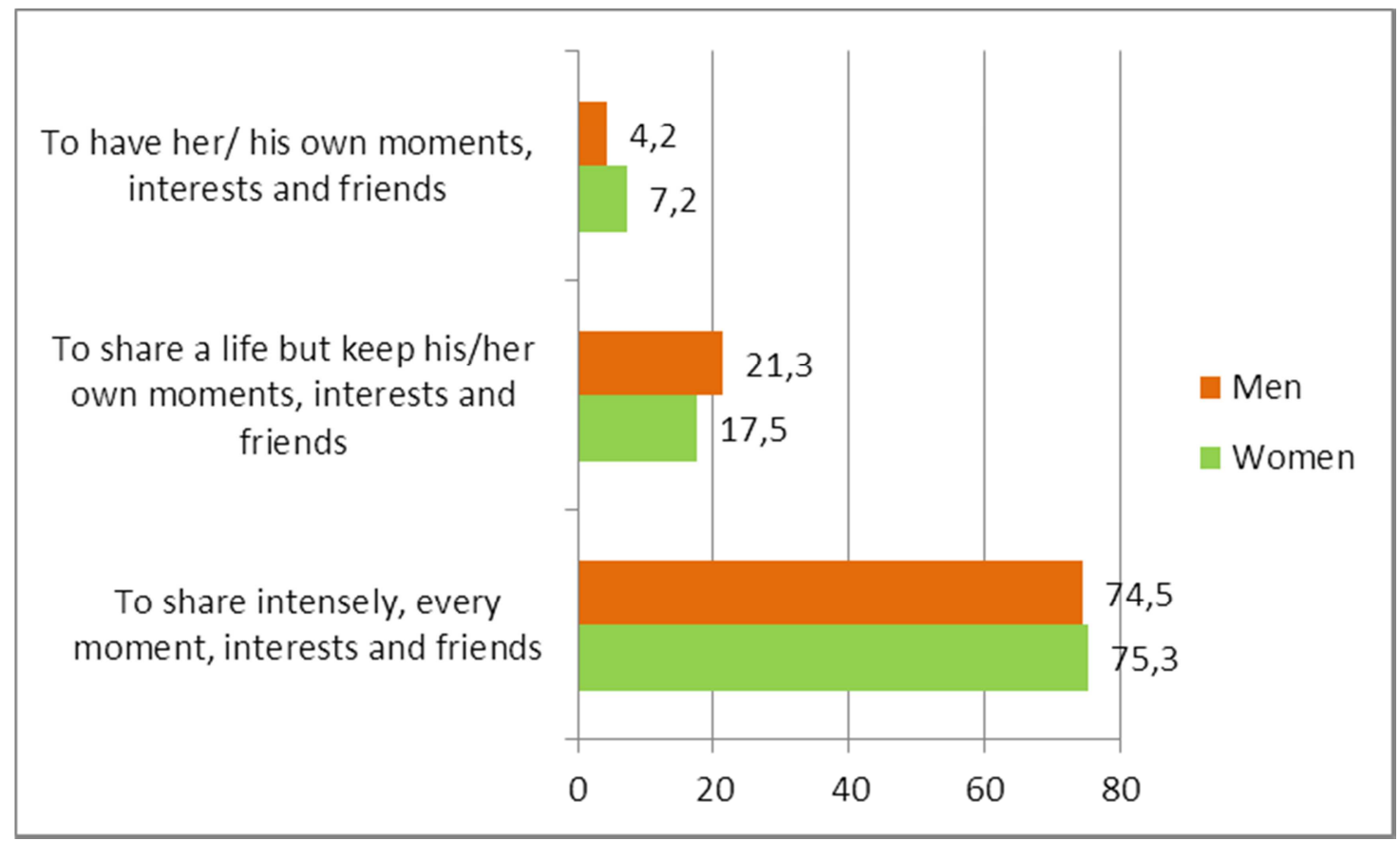

Source: IDG, 2011; N=559 (239 men; 320 women).

Figure 7. Type of relationship with partner, by sex (\%).

Considering the fact that the entry into the conjugality usually entails changes in the level of everyday life, Figure 11 gives an account of the respondents' assessment of changes by sex. Regarding the aspects that have changed after the conjugality, it is observed that the sex affects with more incidence "the amount of domestic tasks". While $48.4 \%$ of the women report that the amount of household chores has changed "for the worse", this is only referenced by $33.1 \%$ of the men, and in this group, the majority said "it was the same" (49, $8 \%: \chi 2=13.48$, $\mathrm{gl}=2.559, \mathrm{p}<0.01)$. In any case, what is notable is the fact that the negative answers are more expressive, in almost all the questions, in the group of the women, although they assume low percentages in the frame of the three options. The aspects in which positive changes with a higher incidence (with percentages above 50\%) are assumed, are, in both sexes, "intimate relationship with (ex-) partner" and "sexual life". In the case of aspects that point to negative changes, those with the highest percentages (between $20 \%$ and $40 \%$ ) refer, both to men and women, to "outgoing and leisure spaces", "the will of study/invest in training" and "personal time to do what he/she wanted ". In addition, "the independence" is observed by $21.6 \%$ of women, while only $13.4 \%$ of men refer to it.

As was evident in the analysis of the changes with the entry into conjugality, with regard to changes in parenting, there were no significant differences in the percentages of self and hetero-evaluations. However, there is also a slight tendency here to assume more improvements in the various dimensions of the (ex-) partner by comparison with own, in which slightly higher percentages are found when it comes to aspects that worsened with the birth of the children.

An analysis related to the gender variable of the respondent tends to show important differences, as indicated in Figure 8. 


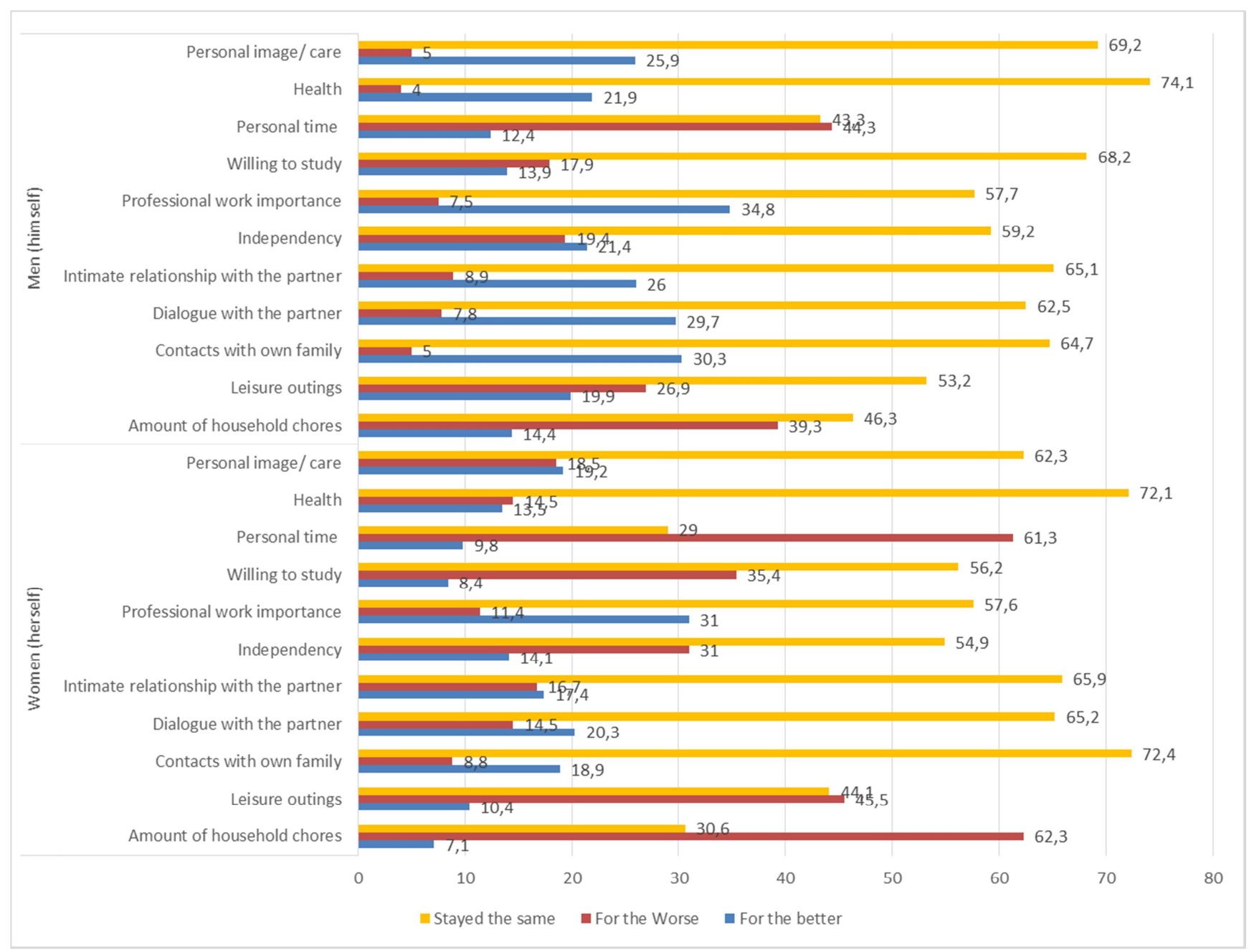

Source: IDG, 2011; N= 497.

Figure 8. Changed life aspects after the children birth (\%).

As Figure 8 points out, people sex affects most of the aspects that have changed after the birth of the children, although men but above all women assume the maintenance of the previous situation with the birth of the children. It is clear that the responses indicative of negative change are in all aspects more pointed out by women than by men. These responses are particularly significant with respect to aspects such as "the amount of household chores" (from 62.3\% to $39.3 \%$ ), "the personal time to do what he/she pleased" (from $61.3 \%$ to $44,3 \%$ ) and "leisure outings" (from $45.5 \%$ to $26.9 \%$ ). On the other hand, they also refer to negative changes in "personal image/ care", "health", "willing to study", "independency" and "intimate relationship with the partner".

The reverse seems to be in the case of the men, who tend to assume improvements more often than women ("contacts with family members": $30.3 \%$ vs $18.9 \%: \chi^{2}=10,14, g l=$ $2,498, p<0,01)$. This happens in almost all itens, although the percentage differences are not accentuated. On the other hand, there are more men to mention that "health", "independence", "intimate relationship with the partner", "contact with own family", "leisure outings" and "Amount of household chores" have changed "for the better". There are also more men reporting that "their personal time to do what they wanted", "the willing to study" and "the amount of household chores" remained the same after the birth of their children.

Still, in relation to the conjugal reality, it is important to assess the dynamics of communication between the parties, to which data - without taking into account gender belonging - shows de following. In the overwhelming majority $(88.3 \%)$ of respondents, they consider that should "should always talk about all subjects", followed by those who consider that "should talk mainly when there are problems" (10.8\%) and very residual $(0.9 \%)$ those who consider that "we should not waste too much time talking". At this level there are no significant differences between men and women, as can be seen from Figure 9. 


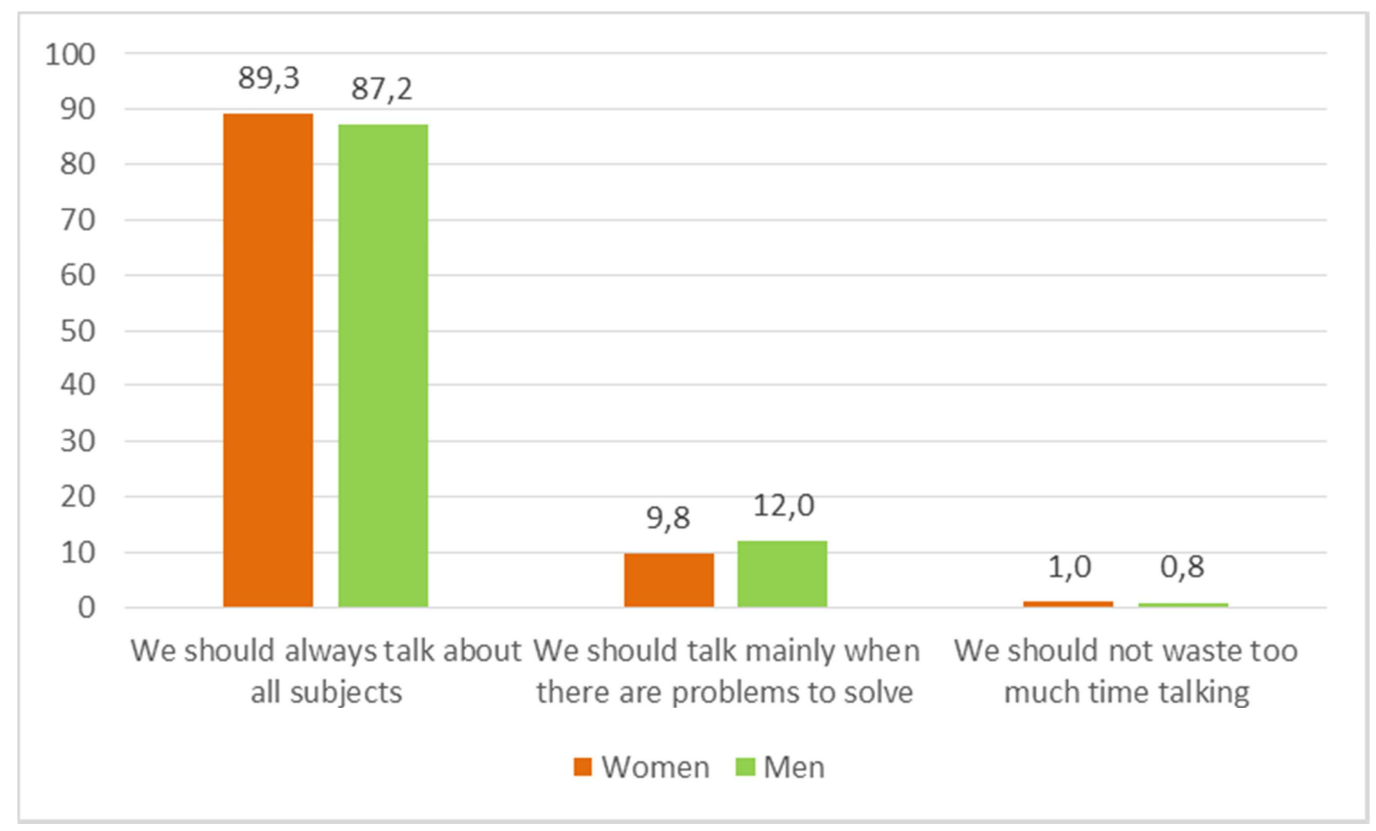

Source: IDG, 2011; N=559 (239 men; 320 women).

Figure 9. Form of communication between members of the couple, by sex (\%).

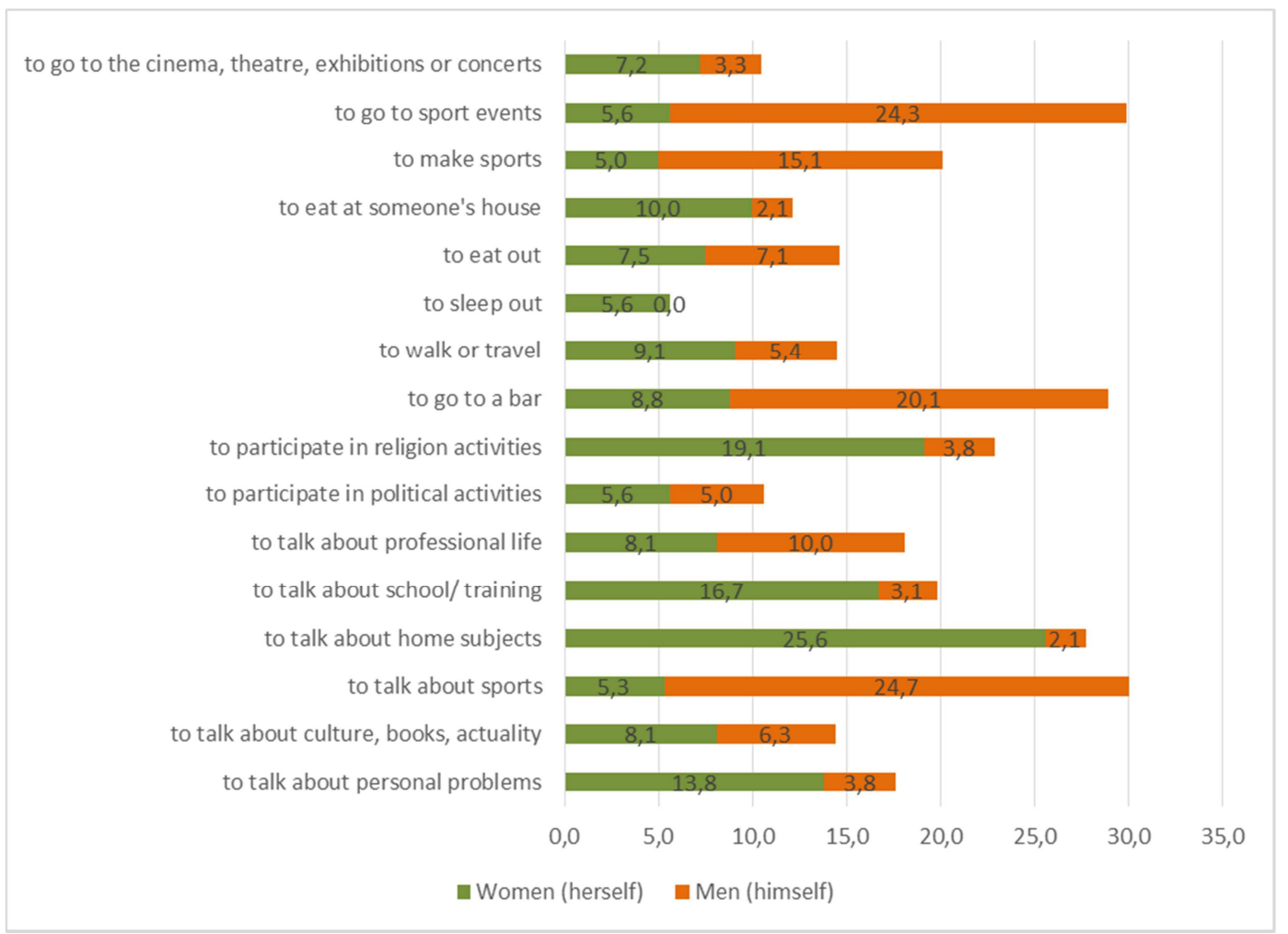

Source: IDG, 2011; N=559 (239 men; 320 women).

Figure 10. Initiative for activities, by sex (\%).

If, in relation to the forms of communication between the members of the couple, practically there are no differences mentioned according to sex or even the professional group or age group, but, concerning the initiatives and positions in diverse subjects in the family, some differences are evident, as we will see next. In the context of couple life dynamics, particularly regarding external initiatives and externe activities and the content of communication within the couple, Figure 10 is illustrative of a greater approximation of values between men and women respondents, even if significant differences are manifested on some itens. Analyzing the data in Figure 10, gender and gender belonging tend to condition concerning those who take some of the initiatives of communicative interaction and 
performing different activities in the couple.

Concerning the communication in the couple, there are differences regarding the initiative of conversations according to the sex of those who tend to initiate them and the content of the same. The conversations related to "home subjects" (25.6\% vs. 2.1\%),"participate in religious activities" (19.1\% vs. $3.8 \%)$, "children school and training" (16.1\% vs. $3.1 \%)$, "personal problems" $(13.8 \%$ vs. $3.8 \%)$ are more pointed out as initiated by women, varying between $25.6 \%$ and $13.8 \%$ and men between $2.1 \%$ and $3.8 \%$. Regarding men, the initiative is more expressive conversations "to talk about sports" ( $24.7 \%$ vs. $5.3 \%)$, "sport events" ( $24.3 \%$ vs. $5.6 \%)$. In close percentagens by two sexes is verifiable "to talk about professional life" ( $10 \%$ vs. $8.1 \%)$, "talk about culture, books and actuality" $(8.1 \%$ vs. $6.3 \%)$ and "to talk about political activities" (5.6\% vs 5\%).

At the level of the initiative in leisure-related activities, slightly higher percentages are shown by women in most options, in company of her husband, "to walk or travel" $(9.1 \%$ vs. $5.4 \%)$, "to sleep in someone's house" $(5.6 \%$ vs $0 \%)$,, "going to the cinema, theater, exhibitions and concerts" (7.2\% vs. 3.3), ranging between $10.0 \%$ and $5.6 \%$, with the variation for men being between $0.0 \%$ and $7.1 \%$ ). Regarding men, there is the initiative is more expressive conversations "to go sport events" ( $24.3 \%$ vs. $5.6 \%)$, "to go to a bar" $(20.1 \%$ vs. $8.8 \%)$, "to make sports ( 15.1 vs. $5 \%)$; and, in close percentages by two sexes, "to eat out or go to a restaurant" (7.5 vs. $7.1 \%)$.

These are, in fact, the activities in which there are more pronounced differences; however, the low proportions of self-attribution in terms of the exclusivity of their initiative in all responses are sometimes highlighted. In fact, having also carried out a bipolarized analysis, it is important to clarify that in most of the items comes the affirmation that the initiatives tend to be shared, but there are some exceptions. In view of the statistical tests carried out, in summary we can say that there are more men taking the initiative to go to "sports shows" $(\mathrm{X} 2=72.67 \mathrm{gl}=6.559, \mathrm{p}<0.001)$, "doing sports" $(\chi 2=26.28, \mathrm{gl}=6.559 \mathrm{p}<0.001)$, "going to the coffee" $(\chi 2=29.13, \mathrm{gl}=6.559, \mathrm{p}<0.001)$ and "talking about sports" " $(\chi 2=98.35, \mathrm{gl}=6.559, \mathrm{p}<0.001)$. The tests also show that there are more women taking the initiative, in the company of her husband, to "sleeping in someone's house" $(\chi 2=16.82, \mathrm{gl}=6.559, \mathrm{p}<0.01)$, "participate in religious activities" (X2 $=33.46, \mathrm{gl}=6.468, \mathrm{p}<0.001)$, "talking about domestic affairs" $(\chi 2=106.16, \mathrm{gl}=6,559, \mathrm{p}<0.001)$ and "talking about personal problems" $(\chi 2=38.17, \mathrm{gl}=6.559, \mathrm{p}$ $<0.001)$.

\section{Conclusions}

Finally, and observing the results from the survey and other sources, it was possible to offer in this paper relevant information on the entry into conjugality, namely the type of marriage - religious, civil or mixed - or the age of marriage; the objectives and motivations for marriage and its hierarchy, as well as its importance. On the other hand, an approximate map of the assets of each respondent and his/her partner and volume of assets before and during the marriage was obtained, a decisive factor for the study of power relations within the house and, in particular, among the members of the couple. Lastly, considering that in the processes of dating, conjugality and marriage are interwoven components of passion and interest, some of the results of this research have allowed access additional information about the processes of understanding and cooperation, modes of conjugal negotiation, bases and ways of building domestic power, as well as some tension dynamics and internal conflicts. This is a scarcely addressed issue in the field of social sciences in Portugal because it is often assumed that in the family sphere there is no place for relations of power; yet these relations do in fact exist, giving rise not only to separations and divorces, but sometimes to more dramatic outcomes.

\section{References}

[1] SHORTER, Edward (1976), The Making of the Modern Family, New York: Basic Books, Inc. Publishers.

[2] FERREIRA, Virgínia (2010),"A evolução das desigualdades entre salários masculinos e femininos: um percurso irregular" in V. Ferreira (ed), A Igualdade de Mulheres e Homens no Trabalho e no Emprego em Portugal - Políticas e Circunstâncias, Lisbon: CITE, pp. 139-190.

[3] SILVA, Manuel Carlos, JORGE, Ana Reis e QUEIROZ, Aleksandra (2012), "Divisão sexual do trabalho doméstico: entre práticas e representações" in Configurações, 9: 135-159.

[4] MARX, Karl [1974 (1867)], O Capital, Lisbon: Delfos.

[5] POULANTZAS, Nicos (1975), Classes in Contemporary Capitalism, London: NLB.

[6] BERTAUX, Daniel (1978), Destinos Sociais e Estrutura de Classes, Lisbon: Moraes Editora.

[7] PARSONS, Talcott (1956), "Family structure and the socialization of the child", in T. Parsons and R. Bales (eds), Family, Socialization and Interaction Process, London: Routledge \& Kegan Paul, pp. 35-131.

[8] DAHRENDORF, Ralph (1959), Class and Class Conflict in Industrial Society, London: Routledge \& Kegan Paul.

[9] GOLDTHORPE, John (1987), Social Mobility and Class Structure in Modern Britain, Oxford: Oxford University Press.

[10] BOURDIEU, Pierre (1980), Le sens pratique, Paris: Minuit.

[11] BRENNER, Johanna e LASLETT, Barbara (1986), "Social Reproduction and the Family" in U. Himmelstrand (org) Sociology: From Crisis to Science?, vol II, The Social Reproduction of Organisation and Culture: 116-131, London: Sage Publications.

[12] BADER, Veit e BENSCHOP, Albert (1988), Ongelijkheden, Groningen: Wolters Noordhoff.

[13] SILVA, Manuel Carlos (1998), Resistir e adaptar-se. Constrangimentos e estratégias camponesas no noroeste de Portugal, Porto: Afrontamento. 
[14] ALMEIDA, Ana Nunes de, SOBRAL, José Manuel e FERRÃO, João (1997), "Destinos cruzados: as estruturas e processos de homogamia" in Análise Social, XXXII, 143-144: 875-898.

[15] WEBER, Max [1978 (1920)], Economy and Society, edited by G. Roth e C. Wittich, Berkeley e London: University of California Press.

[16] GEERTZ, Clifford (1973), The Interpretation of Cultures, New York: Basic Book, Inc.

[17] COTTERIL, P. (1992), "Interviewing women: Issues of friendship, vulnerability and power", in Women's Studies International Forum, 15 (5/6): 593-606

[18] COLLINS, R. (2004), Interaction Ritual Chains, Princeton NJ: Princeton University Press.

[19] BURKIT, I. (2012), "Emotional reflexivity: Feeling emotion in reflexive dialogues", in Sociology, 46 (3): 458-472.

[20] LUHMAN, Niklas [1982 (1970)], The Differentiation of Society, New York: Columbia University Press.

[21] HARRIS, Olivia and YOUNG, Kate (1981), "Engendred Structures: some problems in the analysis of reproduction" in J. S. Khan and J. R. Llobera (eds), The Anthropology of PreCapitalist Societies, London: Macmillan, pp. 109-147.

[22] ENGELS, Friedrich $\{1980$ (1884) $\}$, A origem da família, da propriedade privada e do Estado, Lisbon: Editorial Presença.

[23] ELIAS, Norbert [1982 (1939)], Het civilisatieproces. Sociogenetische en pshicogenetische onderzoekingen, I e II, Utrecht and Antwerpen: Het Spectrum.

[24] FOUCAULT, Michel (1992), Microfísica do poder, Madrid: Ediciones de la Piqueta.

[25] BOURDIEU (1972), "Les stratégies matrimoniales dans le système de reproduction" in Annales, ano XXVII, 4-5: 11051127.

[26] BOURDIEU, Pierre (1998), La Domination Masculine, Paris: Seuil.

[27] WALBY, Sylvia (2007), "Complexity Theory, Systems Theory and Multiple Intersecting Social Inequalities", in Philosophy of Social Sciences, 37 (4): 449-470.

[28] TURNER, J. (2007), Human emotions: a sociological theory, London: Routledge.

[29] BARBALET, J. (2008), Weber, passion and profits: The Protestant ethic and the spirit of capitalism in context, Cambridge: Cambridge University Press.

[30] BEAUVOIR, Simone [2008 (1949)], O Segundo Sexo, Lisbon: Quetzal Editores.

[31] HEANEY, Jonatham (2011), "Emotions and power: reconciling conceptual twins" in Journal of Political Power, vol 4, Issue 2: 259-277.

[32] GOFFMAN, Erving (1974), Les Rites d'interaction, Paris: Éditions du Minuit.

[33] ABBOT, Pamela e WALLACE, Claire (1991), Gender, Power and Sexuality, Basingstoke: MacMilan.

[34] CASACA, Sara Falcão (2012), Trabalho emocional e Trabalho
Estético, Coimbra: Almedina.

[35] SANTOS, Maria Helena e AMÂNCIO, Lígia (2012), "Género e política: análise sobre as resistências nos discursos e nas práticas sociais face à Lei da Paridade", in Sociologia, Problemas Práticas, 68: 79-101.

[36] SCHOUTEN, Maria Joana (2012), Uma Sociologia do Género, Vila Nova de Famalicão: Edições Húmus.

[37] TORRES, Anália (2002), O casamento em Portugal. Uma análise sociológica, Oeiras: Celta.

[38] PARSONS, Talcott [1988 (1951)], El sistema social, Madrid: Alianza Editorial.

[39] FLANDRIN, Jean-Louis (1975), Les amours paysannes (XVIXIX siècles), Paris: Gallimard-Julliard.

[40] SEGALEN, Martine \{1983 (1980)], Love and Power in the Peasant Family. Rural France in the Nineteenh Century, Chicago: The University of Chicago Press.

[41] MEDICK, Hans e SABEAN, David Warren (1984), "Introduction" e "Interest and Emotion in Family and Kinship Studies: a Critique of Social History and Anthropology" in H. Medick e D. W. Sabean (orgs) Interest and Emotion: Essays on the Study of Family and Kinship: 1-27, Cambridge/ Paris: Cambridge University Press e Editions de la Maison des Sciences de l'Homme.

[42] BEREZIN, M. (2009), "Exploring emotions and the economy: new contribution from sociological theory" in Theory and Society, 38 (4): 335-346.

[43] BEATTY, Andrew (2014), "Anthropology and Emotion" in Journal of Royal Anthropological Institut, 20: 545-563.

[44] BERICAT, Eduardo (2016), "The Sociology of Emotions: four decades of progress", in Current Sociology, vol. 64 (3): 491-513.

[45] GERALDES, Alice (1987), Gentes de minifúndio. Produção e reprodução social numa freguesia em mudança, Braga: University of Minho.

[46] ITURRA, Raul $\{1983$ (1976) $\}$ "Estratégias na organização doméstica da produção na Galiza rural» in Ler História, 1: 81-109.

[47] DESCAMPS, Paul (1935), Le Portugal: la vie sociale actuelle, Paris: Firmin-Didot et Cie.

[48] WILLEMS, Emilio (1963), "On Portuguese Family Structure" in K. Ishwaran (org.), International Studies in Sociological and Social Anthropology, vol. I, 65-79, Leiden: E. J. Brill.

[49] SANTO, Moisés Espírito (1980), Freguesia rural ao norte do Tejo, Lisbon: IED.

[50] CABRAL, João Pina (1989), Filhos de Adão, filhas de Eva, A visão do mundo camponesa do Alto Minho, Lisbon: Dom Quixote.

[51] BRETTEL, Caroline (1991), Homens que partem, mulheres que esperam. Consequências da emigração numa freguesia minhota, Lisbon: Publicações Dom Quixote.

[52] ROSA, Rodrigo (2013), Casamento e desigualdade - uma análise da diferenciação social do casal, Lisbon: Imprensa de Ciências Sociais.

[53] SINGLY, François (1987), "Théorie critique de l'homogamie" in L'Année Sociologique, XXXVII: 181-205. 
[54] DUBISCH, Jill (1986), "Introduction" in J. Dubisch (org) Gender \& Power in Rural Greece: 4-41, Princeton, New Jersey: Princeton University Press.

[55] AMÂNCIO, Lígia (1994), Masculino e Feminino. A construção social da diferença, Porto: Afrontamento.

[56] MEILLASSOUX, Claude (1973), "The social organization of the peasantry: the economic basis of kinship" in Journal of Peasant Studies, vol I, 1: 81-91.

[57] PINTO, José Madureira (1985), Estruturas Sociais e Práticas Simbólico-Ideológicas nos Campos, Porto: Afrontamento.

[58] ALMEIDA, João Ferreira (1986), Classes sociais nos campos. Camponeses parciais numa região do Noroeste, Lisbon: Instituto de Ciências Sociais, Universidade de Lisboa.

[59] SANTOS, Boaventura de Sousa (1990), "O Estado e o Direito na transição pós-moderna: para um novo senso comum sobre o poder e o direito" in Revista Crítica de Ciências Sociais, 30: $13-43$.

[60] BRADLEY, Harriet (1999), Gender and Power in the Worplace, London: Macmillan.

[61] ROGER, K. B., SCHRÖDER, T. e VON SCHEVE, C. (2014), "Dissecting the sociability of emotion: a multilevel approach", Emotion Review, 6 (2): 124-133.

[62] KAUFMAN, Jean-Claude [2002 (1992)], O labirinto conjugal. O casal e o seu guarda-roupa, Lisbon: Diário de Notícias.

[63] GIDDENS, Anthony (1992), The Transformation of Intimacy: Sexuality, Love and Eroticism in Modern Societies, Cambridge: Polity Press.

[64] BECK, Ulrich e BECK-GERNSHEIM, E. (1995), The Normal Chaos of Love, Cambridge: Polity Press.

[65] BAUMAN, Zigmund (2001), The Individuated Society, Cambridge: Polity Press.

[66] FORTES, Meyer (1971), "The Developmental Cycle in Domestic Groups" in J. Goody (org), Kinship: 85-98, Harmondsworth: Penguin Books.

[67] GOODY, Jack (1976), Production and Reproduction: a Comparative Study of the Domestic Domain, Cambridge: Cambridge University Press.

[68] DESROSIÈRES, Alain (1978), «Marché matrimonial et structure des classes sociales» in Actes de la Recherche en Sciences Sociales, XX-XXI: 97-107.
[69] DEVILLE, Jean-Claude (1981), « Marriage et homogamie» in Données Sociales (INSEE): 21-30.

[70] KELLERHALS, Jean [1989 (1984)], Microsociologia da Família, Mem Martins: Europa-América.

[71] SEN, Amartía (1998), Nuevo examen de la desigualdad, Madrid: Editorial Alianza.

[72] VALLE, Ana Maria Tepichin (2008), "El género en la pobreza: hacia un balance del avance conceptual" in M. Prieto (ed), Mujeres y escenarios ciudadanos, Quito: FLACSO and Ministerio de Cultura de Ecuador, pp. 83-95.

[73] MORANT, Isabel e BOLUFER, Mónica (2009), «Mujeres y hombres en el matrimonio. Deseos, sentimientos y conflictos» in C. Borderías (org), La historia de las mujeres: perspectivas actuales, Barcelona: Icaria Editorial.

[74] BORDERÍAS, Cristina y PÉREZ-FUENTES, Pilar (2009), "Mujeres, trabajos y economias familiares en España (siglos XIX y XX), in C. Borderías (org.), La historia de las mujeres: perspectivas actuales, Barcelona: Icaria Editorial.

[75] NUNES, João Arriscado e FEIJÓ, Rui (1986),’Household Composition and Social Differentiation in North Western Portugal in Nineteenh Century" in Sociologia Ruralis, vol XXVI, 3: 249-267.

[76] SILVA, Manuel Carlos (1991) "Casa e casas em espaço rural minhoto: o poder doméstico" in Cadernos do Noroeste, vol 4, n.o 6-7: 79-99.

[77] WALL, Karin (1998), Famílias no campo: passado e presente em duas freguesias do Baixo Minho, Lisbon: Dom Quixote.

[78] WALL, Karin (2005), Famílias no Portugal Contemporâneo Percursos, Interacções, Redes Sociais, Lisbon: Imprensa das Ciências Sociais.

[79] SOBRAL, José Manuel (1999), Trajectos: passado e presente na vida de uma freguesia da Beira, Lisbon: Instituto de Ciências Sociais da Universidade de Lisboa.

[80] WALL, Karin, ABOIM, Sofia e CUNHA, Vanessa (orgs.) (2010), A vida familiar no masculino: negociando velhas e novas masculinidades, Lisbon: Comissão para a Igualdade no Trabalho e no Emprego. 